\title{
EXECUTION OF SAFE BLASTING UNDER ADVERSE CONDITIONS OF A POWERHOUSE COMPLEX: A REVISIT TO SARDAR SAROVAR PROJECT, INDIA
}

\author{
Govind Raj Adhikari ${ }^{1,}{ }^{*}$, R. Balachander ${ }^{2}$ and A. I. Theresraj ${ }^{1}$ \\ ${ }^{1}$ Formerly National Institute of Rock Mechanics, Karnataka, India \\ ${ }^{2}$ National Institute of Rock Mechanics, Bangalore, Karnataka, India \\ *Email: gradhikari07@gmail.com; ORCID 0000-0002-5914-1284
}

\begin{abstract}
When the excavation of the underground powerhouse of the Sardar Sarovar Project, India was nearly complete, cracks were observed on the upstream and downstream walls of the powerhouse, and the installed instrumentation readings sounded an alert for the instability of the powerhouse cavern that could possibly derail the project, further excavation in the powerhouse cavern was halted. After completing stabilisation measures, the remaining underground excavations by drill and blast method were to be completed. This paper revisits case studies of controlled blasting for the remaining excavations, namely a construction ramp, turbine pits, draft tube tunnels connecting the powerhouse, and the concrete plugs erected at the exit ends of the draft tube tunnels. To ensure overall stability around the excavations, blast vibration was controlled by planning the excavations in proper sequences. The damage outside the planned line of excavations was controlled by adopting modified line drilling/smooth blasting techniques. The details of the sequence of excavations, drilling and blasting parameters, compiled from previous publications, are presented in this paper. This paper also describes the reasons why concrete plugs were erected in the draft tube tunnels, the details of the concrete plugs, the optimised drilling and blasting procedure for safe removal of the plugs, and the method adopted to quantify the damage.
\end{abstract}

\section{Keywords}

Underground cavern, Controlled blasting, Blast design, Underground excavation.

\section{Introduction}

The Sardar Sarovar (Narmada) Project (SSP), Gujarat, India is one of the largest river valley projects in the state of Gujarat, India. The project constructed a concrete dam of $128 \mathrm{~m}$ high and $1210 \mathrm{~m}$ long across the Narmada river. The underground powerhouse complex comprises six pressure shafts, powerhouse cavern with six turbine units with an installed capacity of
1200 MW (6 x 200 MW), six draft tube tunnels, collection pool and exit tunnels. The layout of the underground structures in the powerhouse complex is shown in Figure 1. 


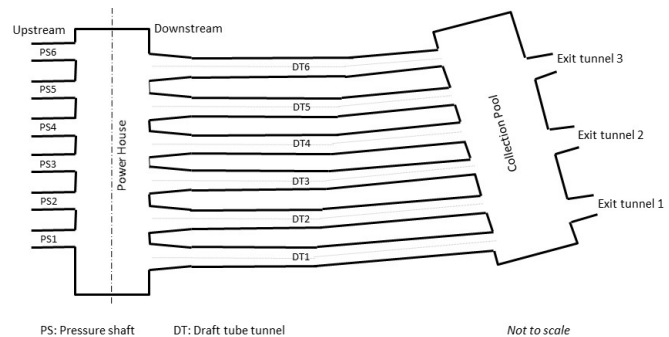

Figure 1: Layout of the underground complex of the Sardar Sarovar Project (Balachander et al., 2002)

The underground powerhouse cavern $(23 \mathrm{~m}$ wide, $56.6 \mathrm{~m}$ high, and $212 \mathrm{~m}$ long) is located in Deccan Basalt flows which are intruded by dolerite dykes and sill. Basalt flows and dolerite rocks are considered good tunneling media for locating underground structures. Therefore, support systems for the powerhouse were initially designed considering good rock mass conditions (Prakash, 2013). Unexpectedly, distress problems were encountered during the excavation of the powerhouse cavern due to the limited depth of cover and the presence of shear zones. Then, the excavation was suspended, and the health of the cavern was assessed through various studies including geological and geotechnical, numerical modeling, installation of additional multipoint borehole extensometers at critical locations, and remedial measures were suggested by various experts to ensure the long-term stability of the cavern. After the stabilisation measures were completed and the recorded instrumentation data indicated the rock movements within tolerable limits, excavation of the cavern had to be resumed. There was a great concern that the drill and blast method might deteriorate the health of the cavern, but there was no alternative to the drill and blast method. Therefore, The National Institute of Rock Mechanics was requested to recommend and execute safer blast designs for the remaining underground excavations. The work scope included excavation of the ramp and turbine pits in the powerhouse, excavation of some critical portions of draft tube tunnels, and removal of the concrete plugs. The excavations were completed successfully about 20 years ago and culminated in four publications (Adhikari et al., 2001a; Adhikari et al., 2001b; Adhikari et al., 2002; Balachander et al., 2002). The objective of this paper is to highlight the strategies adopted for controlled blasting and the results obtained with the explosives and initiation systems available at that time.

\section{Explosives and Accessories Used}

The selection of explosives and initiation systems was constrained by their availability at the site. A cap-sensitive small diameter (dia) aluminised slurry explosive was used. Each cartridge of explosive was $25 \mathrm{~mm}$ dia, $200 \mathrm{~mm}$ long, and weighed $0.125 \mathrm{~kg}$. The density of the explosive was 1.15-1.25 gm/cc and velocity of detonation was $3400-4000 \mathrm{~m} / \mathrm{s}$.

Two types of electric detonators were available at the site. Short delay electric detonators were of zero to 10, with a nominal delay interval of $25 \mathrm{~ms}$ between successive numbers from 1 to 6, $50 \mathrm{~ms}$ for 7 and 8, and $75 \mathrm{~ms}$ for 9 and 10 . Long delay electric detonators were zero to 10 numbers, with a delay interval of $500 \mathrm{~ms}$ between each successive delay number. As the delay periods of either short or long delay detonators were not sufficient, a combination of short and long delay detonators was used to restrict the maximum charge per delay.

\section{Ramp Excavation}

\subsection{Geology and Support Systems}

The powerhouse area comprises lava flows of sub-horizontal basalt, separated by hard 
Nepal Engineers' Association, Gandaki conglomerate and intruded by two dolerite dykes (Prakash, 2013). The rocks are hard but intensively jointed. Basalt is of poor quality $(\mathrm{Q}=9.16, \mathrm{RMR}=60)$, dolerite dyke belongs to good quality $(\mathrm{Q}=10, \mathrm{RMR}=60)$, and dolerite sill is of poor quality $(\mathrm{Q}=0.6-1.25, \mathrm{RMR}=40)$. Rock types and shear zones are shown in the 3D geological log of the cavern (Figure 2). The positions of pressure shafts, draft tube tunnels, and bus galleries are also marked in this figure.

The initial support system consisted of pattern rock bolts, welded wire mesh with $38 \mathrm{~mm}$ layers of shotcrete. However, the 6 to $7.5 \mathrm{~m}$ long rock bolts installed in the sidewalls could not provide adequate restraint to prevent the development of cracks. After cracks were observed on the cavern walls, excavation was suspended and additional treatments to the walls were provided to avert the collapse of the cavern.

Additional supports in the upstream wall consisted of 10.5 to $32 \mathrm{~m}$ long 80-ton capacity cables tensioned to 50 tons and then fully grouted. In addition, $12 \mathrm{~m}$ long $32 \mathrm{~mm}$ dia rock bolts, tensioned to 20 tons, were installed at various locations. In the downstream wall, a large number of $12 \mathrm{~m}$ long $32 \mathrm{~mm}$ dia rock bolts, tensioned to 20 tons before grouting, were installed. In addition to it, a number of 25 $\mathrm{m}$ long 50-ton capacity cables were installed. Remaining excavation in the lower part of the cavern was done by providing $12 \mathrm{~m}$ long tensioned rock bolt support (Prakash, 2013). After the treatment, the magnitude of the deformation recorded was tolerable.

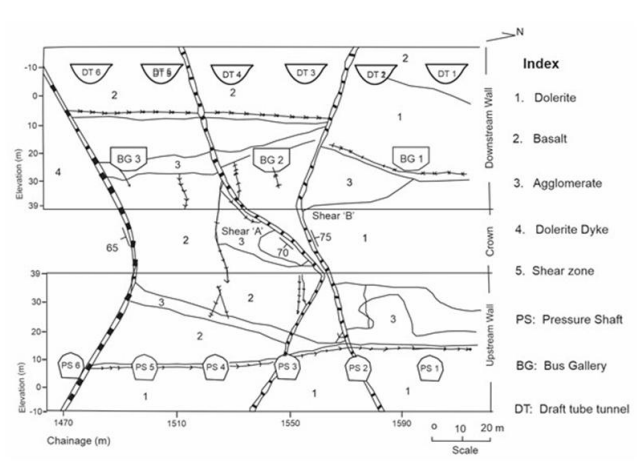

Figure 2: 3D Geological log of the powerhouse cavern at the Sardar Sarovar Project (Prakash, 2013)

\subsection{Details of the Ramp}

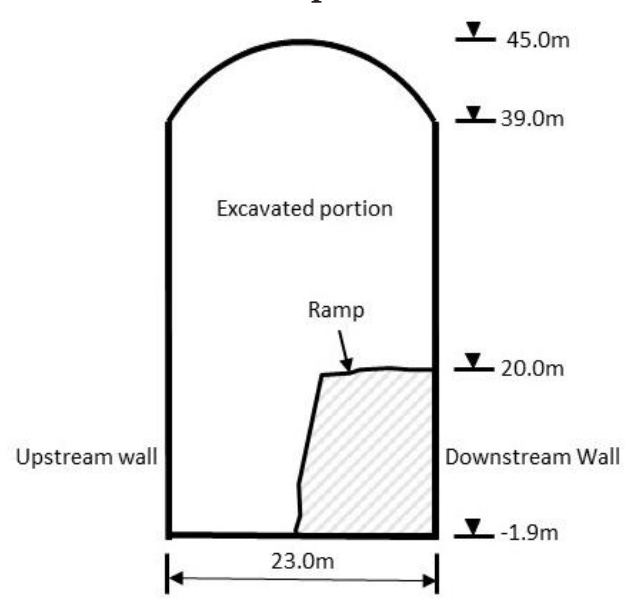

Figure 3: The position of the ramp in the powerhouse cavern before its excavation

(Adhikari et al., 2001a)

A construction ramp (Figure 3) was left along the downstream wall from the service bay $(\mathrm{EL}+20 \mathrm{~m}$ ) to the floor level of the cavern (EL $-2 \mathrm{~m}$ ) on the river side. It was the only access to the floor level of the cavern until draft tube tunnel 1 was broken through. The width was approximately $8 \mathrm{~m}$ on the top and $12 \mathrm{~m}$ at the bottom of the ramp. The estimated volume to be excavated was $15000 \mathrm{~m}^{3}$.

\subsection{Strategy for Ramp Excavation}


The ramp, which was restricting the movement of the downstream wall, was to be excavated under adverse geotechnical conditions, Keeping utmost safety in mind, the ramp was excavated by dividing it into 'main' and 'bark'. The 'main' portion, about $6 \mathrm{~m}$ wide, was advanced by about $6 \mathrm{~m}$ before excavating the 1.5-2 m wide 'bark' portion (Figure 4). The ramp was divided into 11 slices of $2 \mathrm{~m}$ each (Figure 5). Blasting in the ramp progressed from the river side towards the service bay by vertical benching leaving the bark. The exposed wall after removing the bark was provided with immediate support and reinforcement.

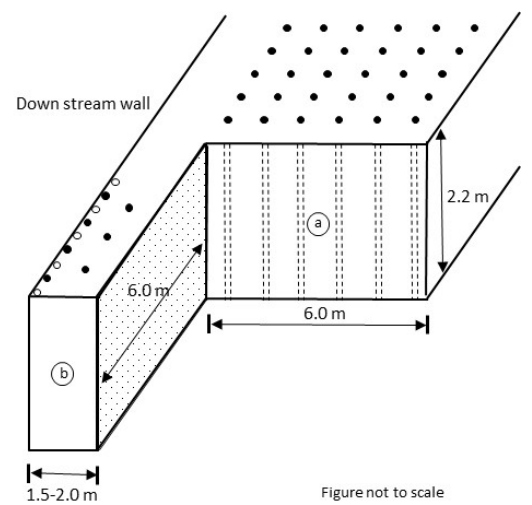

Figure 4: Main (a) and bark (b) portions of the ramp in the powerhouse cavern

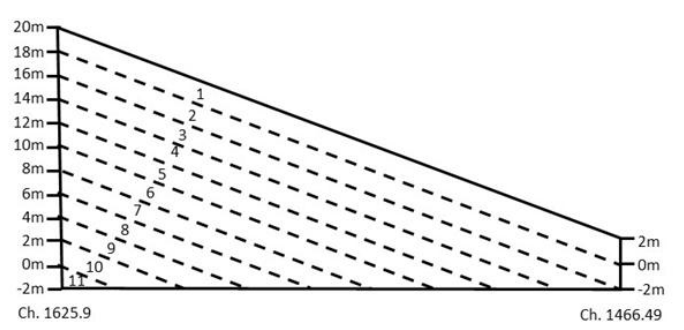

Figure 5: Excavation of the ramp in inclined slices of $2.0 \mathrm{~m}$ each from lower to higher level

\subsection{Review of Earlier Blast Designs}

The blast designs adopted earlier for the deepening of the powerhouse cavern were reviewed to get some ideas from the past experience. Although other alternatives were also tried, the blast design adopted for the benching operations in the cavern is given in Figure 6 (Gupta, et al, 1987). Horizontal holes were drilled to a depth of $2.4 \mathrm{~m}$ with jackhammers. Practically, it was established that the maximum charge per delay of $5.46 \mathrm{~kg}$ and the total charge up to $50 \mathrm{~kg}$ were safe. The specific charge was about $0.54 \mathrm{~kg} / \mathrm{m}^{3}$.

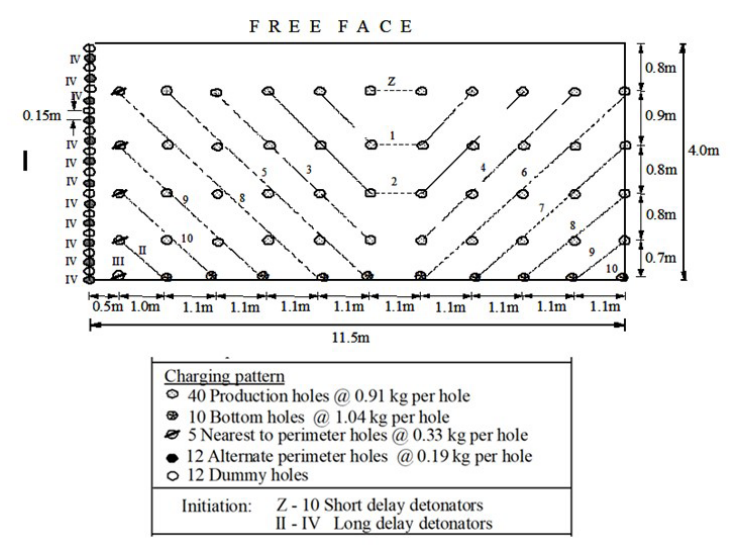

Figure 6: Blast design used for benching operation in the powerhouse (Gupta et al, 1987)

\subsection{Blast Design for Ramp Excavation}

The drill and blast plan for the main portion is shown in Figure 7. Vertical holes of $51 \mathrm{~mm}$ dia were drilled to a depth of about $2.2 \mathrm{~m}$ on a pattern of $1 \mathrm{~m} \times 1 \mathrm{~m}$. Each hole was charged with $0.75 \mathrm{~kg}$ of explosives. When compared to the bench blast used earlier (Figure 6), the specific charge of 0.30 to $0.35 \mathrm{~kg} / \mathrm{m}^{3}$ was lower due to the availability of an additional free face, and the maximum charge per delay, which was restricted to $4.5 \mathrm{~kg}$, was also lower. A V-cut initiation (Figure 7) or sometimes a diagonal cut initiation pattern was used depending on the desired direction of the throw and other site conditions. 


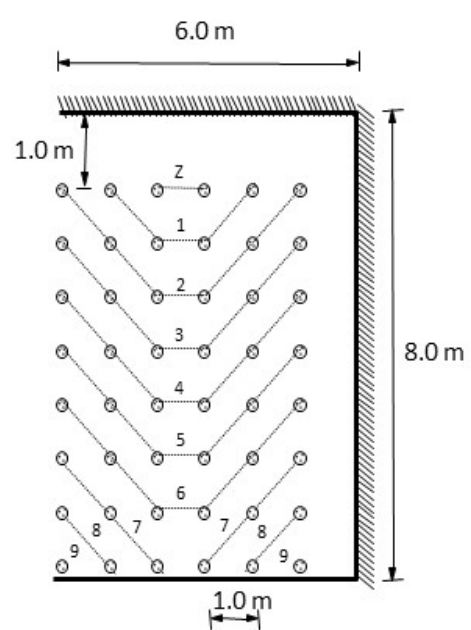

$Z, 1,2 \ldots 9$ are short delay detonators

Figure 7: Blast design for the 'Main' portion

Smooth blasting was adopted for the bark portion of the ramp to reduce the damage on the downstream wall of the cavern (Figure 8). Jackhammer holes of $2 \mathrm{~m}$ deep were drilled. Perimeter holes were drilled at a spacing of 0.2 $\mathrm{m}$ and production holes were $0.5 \mathrm{~m}$ apart from the perimeter holes at the spacing of $0.8 \mathrm{~m}$. The production holes were charged with two to three cartridges per hole while the perimeter holes were charged with two cartridges using spacers, leaving one uncharged hole between two charged holes. In the shear zones, the charge was reduced to two cartridges in production holes and to one cartridge in perimeter holes.
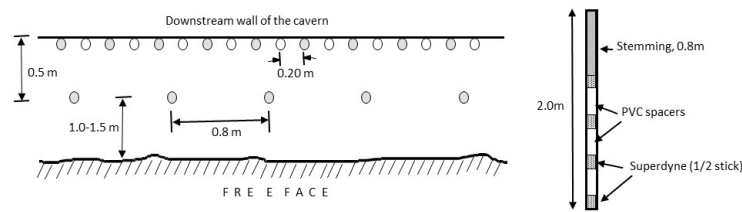

Figure 8: Blast design for the 'Bark' portion

\subsection{Evidence of Safe Excavation of the Ramp}

The following evidence supported that blasting operations for ramp excavation were safe:

- Single and multipoint borehole extensometers installed at strategic locations around the cavern did not indicate any considerable change in the rock mass response during and after the removal of the ramp.

- Blast vibrations during the ramp excavation were lower than those of the bench blasting in the cavern due to availability of an additional free face and lower maximum charge per delay.

- A glass strip, fixed on the river side wall of the bus gallery- 1 where the distress was the maximum, did not show any cracks.

- The profile of the downstream wall, as confirmed by the survey, was satisfactory.

\section{Excavation of Turbine Pits}

\subsection{Details of the Turbine Pits}

Figure 9 shows the layout and dimensions of the six turbine pits. These pits were excavated from (-) $1.9 \mathrm{~m}$ level to (-) $11.6 \mathrm{~m}$ level, that is, to a depth of $9.7 \mathrm{~m}$. The pits were $18 \mathrm{~m}$ wide on the downstream wall, $7.0 \mathrm{~m}$ on the upstream wall, and $17.7 \mathrm{~m}$ long. The dimension of the pits was decided by the dimension of the turbine units. The rock ledge between the pits was only $7.0 \mathrm{~m}$ and full column grouted rock bolts were provided in the ledges from (-)1.9 m level to (-)11.6 m before commencing the excavation of the pits.

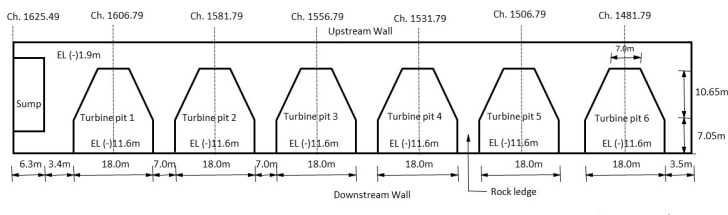

Figure 9: Layout of turbine pits to be excavated in the powerhouse cavern (Adhikari et al., 2002)

\subsection{Strategy for Excavation by Blasting}

The turbine pits were excavated at three stages (Figure 10) to minimise the damage to wall rocks, the foundation of the pits, and the rock 
ledges, and to ensure the overall stability of the powerhouse cavern. Blast designs for different stages were prepared by integrating the fundamentals of controlled blasting with the experience obtained from the ramp removal.

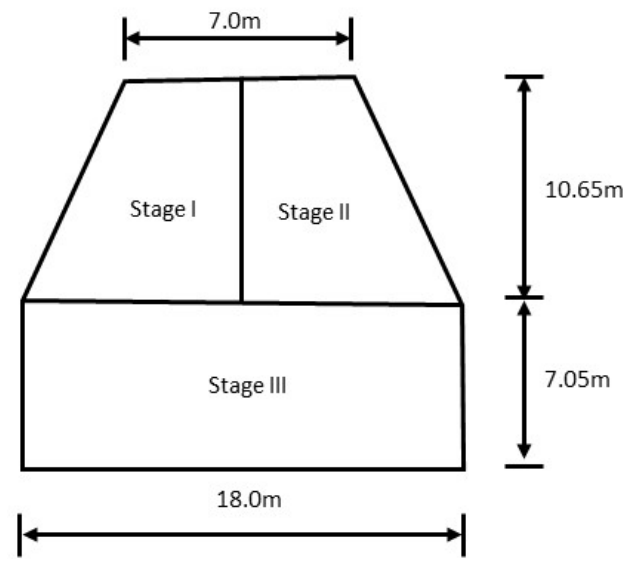

Figure 10: The sequence of excavation of turbine pits (Adhikari et al., 2002)

Stage-I excavation had no free faces. Holes of $51 \mathrm{~mm}$ dia were drilled in a wedge cut pattern to a depth of 2.0 to $2.2 \mathrm{~m}$. The spacing of the perimeter holes was $0.3 \mathrm{~m}$. All production holes were charged with six cartridges per hole, the holes adjacent to the perimeter holes were charged with four cartridges and the alternate perimeter holes were charged with 2 cartridges per hole. Thus, the ratio of charges for production, adjacent to the perimeter and the perimeter holes was 3:2:1. The drilling, charging and initiation pattern for Stage-I is given in Figure 11.

Stage-I excavation created an additional free face for Stage-II. Therefore, $51 \mathrm{~mm}$ dia vertical holes were drilled on spacing and burden of 1.0 $\mathrm{m} \times 1.0 \mathrm{~m}$. The charging pattern was the same as that of Stage-I but the initiation pattern was different. The blast design for Stage-II is given in Figure 12.
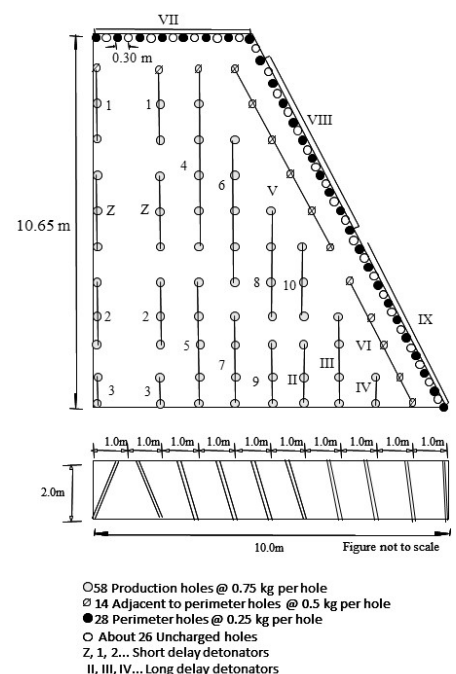

Figure 11: Blast design for the excavation of the turbine pits (Stage-I) (Adhikari et al., 2002)

Blast design for Stage-III (Figure 13) was in principle similar to that for Stage-II. The details of the design parameters for different stages are given in Table 1. Based on the experience of the ramp excavation, the maximum charge per delay was restricted to $4.5 \mathrm{~kg}$ to control ground vibration. Alternate holes along the perimeter were charged, which permitted wider spacing of $0.3 \mathrm{~m}$ for perimeter holes than in line drilling.

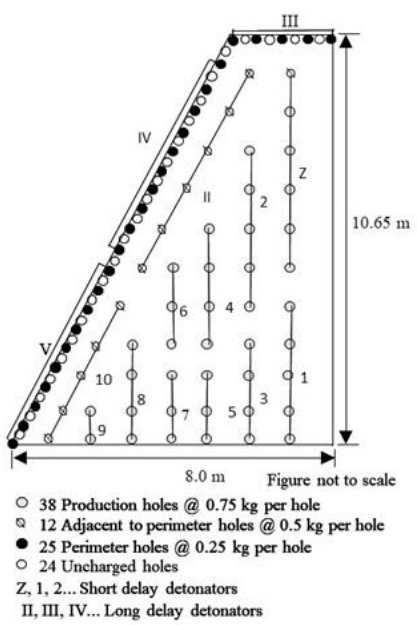

Figure 12: Blast design for the excavation of the turbine pits (Stage-II) (Adhikari et al., 2002) 


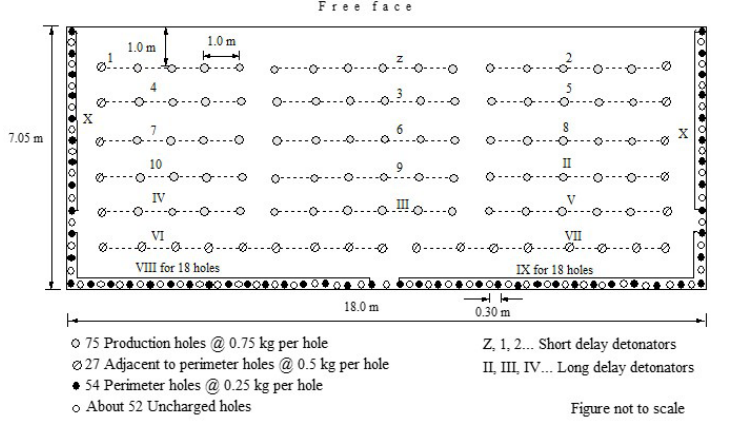

Figure 13: Blast design for excavation of the turbine pit (Stage-III) (Adhikari et al., 2002)

Two explosive cartridges with detonating cord were loaded at the bottom of the perimeter holes. A paper plug was pushed into the hole up to the depth of $0.8 \mathrm{~m}$ to create an air gap and the upper portion was stemmed. Detonating cord having $10 \mathrm{~g}$ of PETN per meter was used as a decoupled charge in perimeter holes as well as simultaneous firing of a group of perimeter holes.

The exposed walls of the pits were supported concurrently. The support system included two layers of $38 \mathrm{~mm}$ thick shotcrete, with wire mesh in between and 25-32 $\mathrm{mm}$ dia, 6-12 $\mathrm{m}$ long fully grouted rock bolts at $1.5 \mathrm{~m} \times 1.0 \mathrm{~m}$ staggered.

Table 1: Details of the blast design for different stages of excavation of turbine pits

\begin{tabular}{|l|c|c|c|}
\hline Parameters & Stage I & Stage II & Stage III \\
\hline Hole diameter, $\mathrm{mm}$ & 51 & 51 & 51 \\
\hline Drill hole pattern & Wedge cut & Vertical & Vertical \\
\hline Hole depth, $\mathrm{m}$ & $2.0-2.2$ & $2.0-2.2$ & $2.0-2.2$ \\
\hline Total charge, $\mathrm{kg}$ & 57.5 & 42.0 & 83.25 \\
\hline Maximum charge per delay, $\mathrm{kg}$ & 4.5 & 4.25 & 4.5 \\
\hline Volume of excavation, $\mathrm{m}^{3}$ & 155 & 112 & 254 \\
\hline Specific charge, $\mathrm{kg} / \mathrm{m}^{3}$ & 0.37 & 0.37 & 0.33 \\
\hline Specific drilling, $\mathrm{m} / \mathrm{m}^{3}$ & 1.70 & 1.87 & 1.71 \\
\hline
\end{tabular}

\subsection{Evidence of Controlled Blasting}

The measured ground vibrations were comparable to those of the ramp excavation. Extensometer readings did not indicate any appreciable movement in the walls of the powerhouse cavern.

The deviation of the actual line of excavation from the vertical, called off-set was surveyed at different depths in two perpendicular directions from the centre of the pits. Figure 14 shows the off-sets against the depth of four turbine pits on the access tunnel side, river side and upstream side walls of the pits. The off-sets were limited to 0.5 to $0.6 \mathrm{~m}$. A few abnormal off-sets were possibly due to the adverse geological condition which was aggravated by the cuts in the rock ledges to facilitate the muck removal as the excavation of the DTs were not completed.
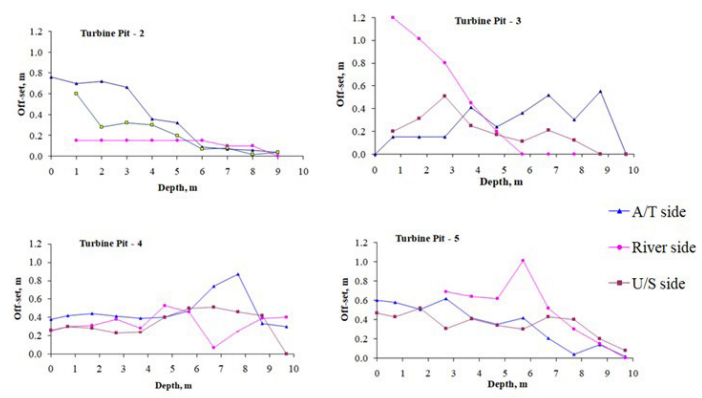

Figure 14: Measured off-sets at different depth of turbine pits on the access tunnel (A/T) side, river side and upstream (U/S) side walls (Adhikari et al., 2002) 


\section{Excavation of draft tube tunnels}

\subsection{Description of DTs}

As per the design, there were six draft tube tunnels (Figure 1). The length of the DTs varied from $150 \mathrm{~m}$ to $175 \mathrm{~m}$, and the finished and excavated diameter were $10.0 \mathrm{~m}$ and $11.1 \mathrm{~m}$ respectively, but the diameter varied from the downstream wall of the powerhouse towards the collection pool over a length of $30 \mathrm{~m}$. The minimum rock ledge between DTs was $9.0 \mathrm{~m}$ adjoining the powerhouse, which gradually increased to $13.0 \mathrm{~m}$ at $30.0 \mathrm{~m}$ chainage and was constant thereafter.

\subsection{Sequence of Excavation of DT}

DT6 was excavated by double barrel section up to $8.0 \mathrm{~m}$ and thereafter it was excavated in a single barrel. The sequence of the excavation for double and single barrel sections are shown in Figure 15. The heading portion of the river side was excavated first to minimise the damage to the rock ledge between two successive DTs. The wedge cut method was used. It was followed by a heading portion on the river side by drilling horizontal holes as it had an additional free face created by wedge cut drilling. The drill depth for both the headings was $2.0 \mathrm{~m}$. After excavating both the headings, supports were installed without delay. Later, bench blasting by drilling 2.0 horizontal holes was adopted in river side portion followed by access tunnel side.

For excavation of the double barrel, 34-38 mm dia holes were drilled with jackhammers at all the excavation stages except for Stage-III and IV for which $51 \mathrm{~mm}$ dia horizontal holes were drilled. Similarly, for excavation of the single barrel, holes were drilled with jackhammers at all stages except stage-II for which $51 \mathrm{~mm}$ dia holes were drilled.
Figure 15: Sequence of excavation in draft tube tunnels (Balachander et al, 2002)

\subsection{Overbreak Analysis During Excavation by Heading}

As the overbreak is mostly caused by the perimeter and next to the perimeter holes, the charge concentration was reduced in these holes. After each blast, the overbreak was measured to compare the excavated profiles with the designed ones at different chainages. The designed and excavated cross-sections of DT 6 at different chainages are shown in Figure 16. The overbreak is more on the riverside of the DT as shear zone along its side for about 6 $\mathrm{m}$, affecting the overbreak for a length of about 5-6 $\mathrm{m}$ on the same side and at the same position of the tunnel. The overbreak is the least at $16 \mathrm{~m}$ chainage, outside the shear zone. 
Nepal Engineers' Association, Gandaki
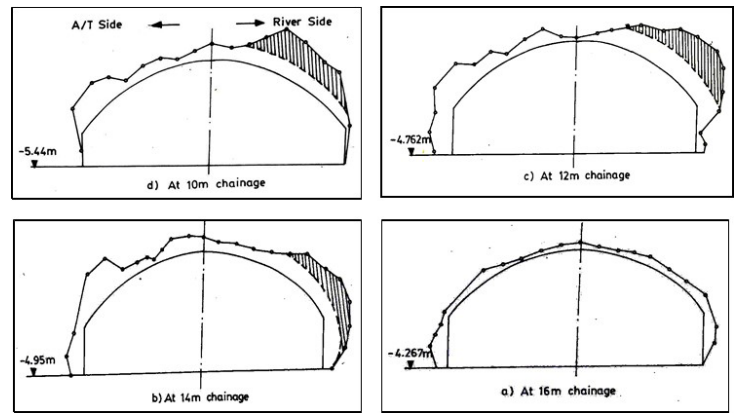

Figure 16: Designed and actual line of excavation of DT at different cross-sections

(Balachander et al., 2002)

\subsection{Excavation of Rock Pier}

The excavation of DT was completed leaving a rock pier of $1.0 \mathrm{~m}$ on either side of the tunnel for the sequences III to VI in Figure 15. The rock pier was left in the double barrel portion because the columns erected in the heading portion were resting on these rock ledges or "rock piers". These piers had to be removed to extend the column supports. Removal of these rock piers was critical because they were taking loads of the downstream wall of the powerhouse cavern. The following sequence was adopted to excavate the rock piers from the downstream side of the powerhouse to minimise the span of openings during drilling, blasting, and supporting operations.

- Removal of the rock ledge on the riverside for a length of one meter and extending the ISMB (Indian Standard Medium weight Beams) column in the excavated portion.

- Removal of the rock ledge on the access tunnel side for a length of one meter, and extending the ISBM column in the excavated portion.

- Removal of the rock ledge below the middle column for one meter, and extending the ISBM column in the excavated portion.

- Repeating the above steps till completion.

These rock piers were drilled and blasted using horizontal holes. After removing one meter, two columns of supports were provided in the excavated portion.

\section{Removal of Concrete Plugs In Draft Tube Tunnels}

\subsection{Reasons for Installing Concrete Plugs}

During the construction of the project, an unprecedented flood entered the powerhouse through the exit tunnels, collection pool, and draft tube tunnels (DTs) and caused damage to underground structures. After this incident, these draft tubes were plugged with concrete/ reinforced concrete to prevent future flooding. After heavy gates were erected at the exit ends of the draft tube tunnels, the plugs had to be removed by drilling and blasting without causing any damage to the concrete lining and the ribs erected in the tunnels.

\subsection{Details of the Concrete Plugs}

The length of the concrete plugs in DT- 1 and DT-2 was $16 \mathrm{~m}$. The plugs were D-shaped with a height of $10.0 \mathrm{~m}$ and the width of $8.5 \mathrm{~m}$ to $10.0 \mathrm{~m}$. The ribs were installed at an interval of $0.75 \mathrm{~m}$. Steel reinforcement rods of $20 \mathrm{~mm}$ dia were also provided at $0.3 \mathrm{~m}$ spacing in both horizontal and vertical directions. Additionally, $25 \mathrm{~mm}$ dia and $4.0 \mathrm{~m}$ long anchors were grouted in the crown and sides of the tunnel. In DT-1, the plug was lined for $5 \mathrm{~m}$, while only ribs were erected for another $11 \mathrm{~m}$. In DT-2, linings were completed for $11 \mathrm{~m}$, while the unlined portion was for only $5 \mathrm{~m}$. The first $1 \mathrm{~m}$ of the plug from the collection pool side was made of concrete M20 MSA20 and for another $15 \mathrm{~m}$, it was made of two grades of concrete. The lower portion was plugged with M10 MSA150 and the upper portion was plugged with M20 MSA20. M20 MSA20 indicates the compressive strength of 
$20 \mathrm{MPa}$ and the maximum size of aggregate of $20 \mathrm{~mm}$ whereas M10 MSA150 grade indicates the compressive strength of $10 \mathrm{MPa}$ and the maximum size of aggregate of $150 \mathrm{~mm}$. The longitudinal section of the plug is shown in Figure 17.

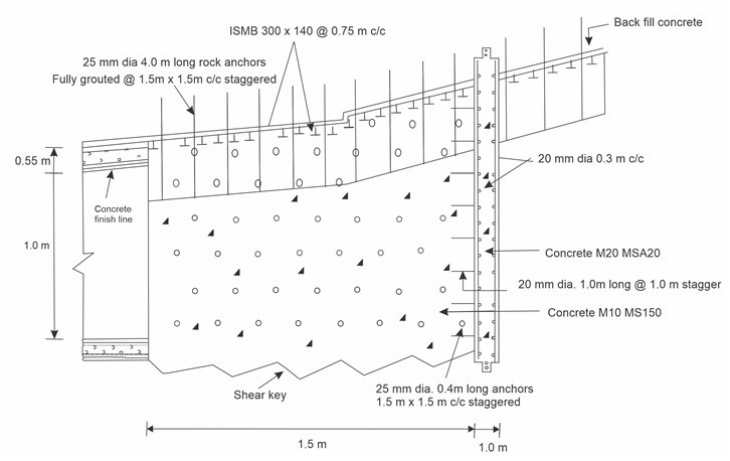

Figure 17: Longitudinal section of the concrete plug in DT-1 and DT-2 (Adhikari et al., 2001b).

\subsection{Drilling and Blasting in the Heading}

The concrete plug was removed by heading and benching method. A heading of $5.0 \mathrm{~m}$ height was excavated from the powerhouse side by drilling 34-38 mm dia holes to a depth of $1.5 \mathrm{~m}$ in a wedge cut pattern (Figure 18). Due to the risk of damage to the lining, the perimeter holes were drilled $0.2 \mathrm{~m}$ away from the perimeter as the contact between the concrete lining and plug behaved as a weak plane. The perimeter holes were drilled at a spacing of $0.3 \mathrm{~m}$. The details of charging are given in Table 2. The maximum charge per delay was restricted to $6 \mathrm{~kg}$. The total charge per round was 60.75 $\mathrm{kg}$ but it varied from 55 to $65 \mathrm{~kg}$ depending on the face condition and the cross-sectional area. The number of holes varied from 95 to 110 without changing the number and position of cut holes. In the plugs where the ribs were erected but the lining was not completed, the charge in the perimeter holes was equivalent to that in production holes so as to expose the ribs completely.

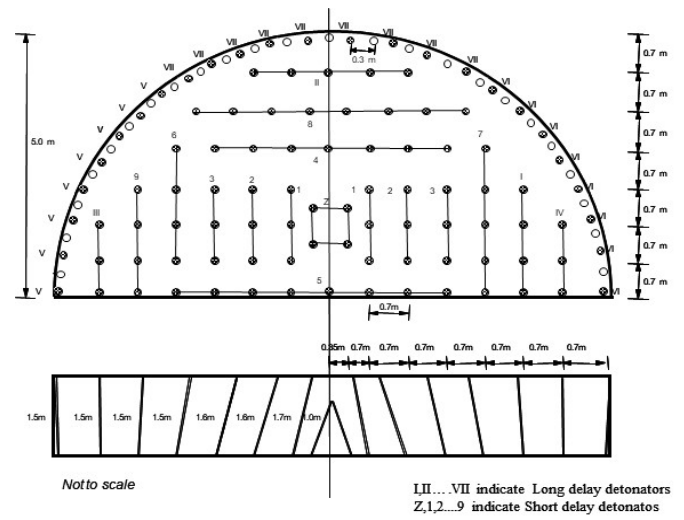

Figure 18: Blast design for the removal of concrete plugs (Adhikari et al., 2001b)

Table 2: Charging details in the headings of the concrete plug

\begin{tabular}{|c|c|c|c|c|}
\hline $\begin{array}{l}\text { Delay } \\
\text { No }\end{array}$ & $\begin{array}{l}\text { No of } \\
\text { holes }\end{array}$ & $\begin{array}{l}\text { No of } \\
\text { cartridges }\end{array}$ & $\begin{array}{l}\text { No of } \\
\text { cartridges } \\
\text { per delay }\end{array}$ & $\begin{array}{l}\text { Charge } \\
\text { weight per } \\
\text { delay (kg) }\end{array}$ \\
\hline Z & 4 & 4 & 16 & 2.0 \\
\hline 1 & 6 & 6 & 36 & 4.5 \\
\hline 2 & 6 & 6 & 36 & 4.5 \\
\hline 3 & 6 & 6 & 36 & 4.5 \\
\hline 4 & 7 & 6 & 42 & 5.25 \\
\hline 5 & 7 & 6 & 42 & 5.25 \\
\hline 6 & 5 & 6 & 30 & 3.75 \\
\hline 7 & 5 & 6 & 30 & 3.75 \\
\hline 8 & 8 & 6 & 48 & 6.0 \\
\hline 9 & 4 & 6 & 24 & 3.0 \\
\hline I & 4 & 6 & 24 & 3.0 \\
\hline II & 5 & 6 & 30 & 3.75 \\
\hline III & 3 & 6 & 18 & 3.75 \\
\hline IV & 4 & 6 & 24 & 3.0 \\
\hline V & 8 & 2 & 16 & 2.0 \\
\hline VI & 8 & 2 & 16 & 2.0 \\
\hline VII & 9 & 2 & 18 & 2.25 \\
\hline Total & 99 & 88 & 486 & 60.75 \\
\hline
\end{tabular}

It was desirable to use low density, low strength explosives for the perimeter holes. Since such an explosive was not available at the site, holes were charged with explosive cartridges using an air deck to lower the peak pressure below 
Nepal Engineers' Association, Gandaki

the dynamic crushing strength of the concrete to reduce crushing and fracturing near the hole. In order to eliminate any untoward incident, safety rules related to electric firings were strictly followed. As a precaution, welding work in the powerhouse complex was suspended during charging and blasting of holes.

\subsection{Specific Observations}

Drilling in reinforced concrete was difficult due to the obstruction by anchors and dewatering pipe. Although the compressive strength of M20 was greater than M10, drilling and blasting was easier in M20 compared to M10 concrete. Some holes also got jammed in the M10 concrete portion because of the size of the aggregates. Dry drilling of holes produced excessive dust whereas wet drilling caused frequent rod jamming. The dust problem with dry drilling was minimised by removing the plug from the collection pool side taking advantage of natural ventilation. The steel rod reinforcement exposed after blasting required arc cutting. Breakage was poor wherever ventilation pipes and reinforcement rods obstructed proper drilling. The concrete entrapped between the ribs, which did not come out with face blasting was removed by drilling short holes and charging them lightly, or by rock breakers.

\subsection{Quantification of Blasting Damage}

No visible damage due to blasting was noticed on the concrete linings but some amount of damage was inevitable. Therefore, P-wave velocity was used to quantify the damage caused by blasting (Adhikari et al., 2001b). The P-wave velocity was measured using a seismic digital counter, Handy Seis PS-1, manufactured by OYO Corporation, Japan. The geophone was fixed on the wall of the tunnel while the position of the hammer switch was varied keeping a minimum distance of $2.5 \mathrm{~m}$ between the geophone and the hammer switch. The travel times measured for the concrete plug portion and behind it on both the walls of the tunnel. P-wave velocity measured behind the plug portion of the tunnel was considered as the P-wave velocity of the concrete lining unaffected by blasts, as the quality of concrete lining in the plug portion and immediately behind it was the same. After the concrete plugs were removed, P-wave velocity was also measured in the walls of the concrete plug portion of the tunnel. Average P-wave velocities were calculated separately for both walls of the tunnels. In this method, damage is quantified by the reduction in P-wave velocity, which varied from 9 to 13 percent on the side walls of DT1 and 13 percent in DT2. Therefore, the damage caused by the blasting was limited to $13 \%$ on the side walls.

\section{Conclusions}

Although the conditions of the underground structures at Sardar Sarovar Project were critical, application of scientific knowledge and proper execution of controlled blasting led to successful completion of the remaining excavations. The basic approaches adopted and the major findings of the studies are:

- Due to the critical condition of the powerhouse cavern, the ramp was divided into main and bark for safe excavation. The turbine pits were also excavated in three stages by blasting in a controlled way.

- For stability of large underground openings, controlled blasting alone was not an effective solution. Timely installation of proper supports around the openings was 
equally important to prevent rock mass from deteriorating.

- Besides vibration monitoring, the impact of blasts on the roof and walls of large underground openings were evaluated by instrumentation like multi-point borehole extensometers. In the reported studies, the measured ground vibrations were low and no adverse effects were noticed in the powerhouse walls or turbine pits. Extensometer readings also indicated insignificant movements in the walls of the powerhouse cavern.

- When the size of the draft tube tunnels varied, the number of drill holes and the quantity of explosives were adjusted accordingly in the same basic blast design.

- The deviations of the actual line of excavation from the designed vertical walls of the turbine pit were limited to $0.5 \mathrm{~m}$. The excessive overbreak in some sections was due to unfavorable geology.

- Drilling in M10 MSA150 concrete was extremely difficult. Wet drilling of the holes led to jamming the holes/loss of holes while dry drilling produced excessive dust. The concrete between the ribs, which did not come out along with the main blast, was removed by stripping blasts, and by rock breakers. The contact between the concrete lining in the tunnel and the plug behaved like a weak plane and helped in achieving smooth profiles.

- The reduction in the seismic wave velocity in the tunnel linings, not subjected to blasting and the tunnel linings affected by blasting was successfully used to quantify the blasting damage. The effect of blasting on the concrete linings in the plug portions of the draft tune tunnels was limited to
9-13 percent.

- The strategy adopted for underground excavations by the authors can be applied in other projects, but electric detonators need to be substituted by shock tube/ electronic initiation systems.

\section{References}

Adhikari, G. R., Balachander, R. Theresraj, A.I., and Gupta, R. N., 2001a. "All under control", Tunnels $\mathcal{E}$ Tunnelling International, September, pp. 20-22.

Adhikari, G. R., Theresraj, A.I., Balachander, R. and Gupta, R. N., 2001b. "Controlled blasting for removal of concrete plugs in draft tube tunnel at Sardar Sarovar Project", FRAGBLAST - Int. J. for Blasting and Fragmentation, Vol. 5, No. 4, pp. 221-234.

Adhikari, G. R., Balachander, R., Verma, H.K. and Gupta, R. N., 2002. "Excavation of turbine pits for a hydroelectric project - a case study", J. of Rock Mechanics $\mathcal{E}$ Tunnelling Tech. Vol.8, No.2, pp. 127-139.

Balachander, R., Adhikari G. R. and Gupta R. N. 2002. "Excavation of draft tube tunnels for Sardar Sarovar Project", INDOROCK, New Delhi, November, 253-259.

Gupta, R.N., Singh, M.M. and Singh, B., 1987. "Application of presplitting and smooth blasting for a large power house cavern", Proc. 28th US Symp. on Rock Mechanics, Tucson, 29 June-1 July, pp. 909-917.

Prakash,I., 2013. “ Application of observational method in the successful construction of underground structures, Sardar Sarovar (Narmada) Project, Gujarat, India", Int. Conf. on Case Histories in Geotechnical Engg. http://scholarsmine.mst.edu/ icchge/7icchge/session01/7. 